\title{
Drawapala Tanding Corona: Global Local Representation of Batik Pattern
}

\author{
Fatmawati $^{1}$, Romy Setiawan ${ }^{2}$, Dyanningrum Pradhikta ${ }^{3}$ \\ \{fatma@ub.ac.id ${ }^{1}$,romybelajar@ub.ac.id², ade.pradhikta@ub.ac.id ${ }^{3}$ \} \\ Universitas Brawijaya, Indonesia ${ }^{1,2,3}$
}

\begin{abstract}
The development of local batik pattern manifests a potential development of new batik patterns. When many regions have developed the batik potencies they have, several other regions are in the process of exploring theirs by new batik creation and innovations which are perceived to have standout unique motifs. Meanings and symbols in Dwarapala are manifested in Malang batik motifs. The research method used was Chapman's visual art creation which comprised three stages. Before embodying a product, we had to refine the motifs and select the colors which should refer to the philosophical meanings of Dwarapala. Creating Dwarapala batik motifs not only signified motif exploration but also delivered markers and encouragement to Malang people. These intentions pertained to the existence of Arca Dwarapala, which was the combination of the word dwara (gate) and pala (keeper). The motif symbolized a gatekeeper who protected Malang people from foreign attacks (the Coronavirus). Accordingly, re-exploring local values during disasters (pandemic) was pivotal to evoke the spirit of resistance and endurance during crises. Additionally, the Dwarapala batik motif would be a reminiscent artifact which marked a certain era, through which the future generation would be able to remind of past events.
\end{abstract}

Keywords: Dwarapala, Corona, Batik Pattern, Exploration

\section{Introduction}

Due to this pandemic, a new setting of life is created and urges humans to be more adaptive and creative to survive. All communities, including artists, have modified their old lifestyles and regularities. However, at the same time, the pandemic has boosted creativeness in artists, allowing them to create innovations related to either ideas, materials, concepts, techniques, or presentation. An artistic world, which is always presented in public spaces and calls for direct engagement from the community, becomes personal and virtual. The materials on tradition, which had been merely decorative exploration, now enable us to explore through conventions and make a dialogue with today's issues. The massive creations of Javanese batik motifs coherently composited with the visualization of Coronavirus attest how traditions are creative and adaptive to whatever era they exist. In other words, batik motifs can be derived from what is going on and what materials are used today. In our research, the ornament Arca Dwarapala in Singhasari Temple Malang and the pandemic are selected to be the underlying idea in creating the Dwarapala batik motif.

In batik, symbols and marks are two typical keys to deliver ideas and insights to art connoisseurs (wearers) well. Setiawan [1] had studied the embodiment of batik motif as a cultural heritage in Malang in the form of Arca Dwarapala in Singhasari Temple. Some icons were extracted through a stylization of the shapes and ornaments on Arca Dwarapala in 
Singhasari Temple, e.g., Dwarapala, the head of Dwarapala, skull ornaments, snake ornaments, cudgels, hands in a Mudra position, and tendrils. The shapes and ornaments selected were those unique and prominent and represented Dwarapala's characters, meanings, and philosophies.

Creating Dwarapala batik motifs not only signifies motif exploration but also delivers markers and encouragement to Malang people. These intentions pertain to the existence of Arca Dwarapala, which is the combination of the word dwara (gate) and pala (keeper). Margaret and James [2], believes that $d$ wara means a portal or gate, with a supreme symbolic meaning during the early Veda era, which leads to sacred or important sites, such as temples, palaces, or houses. The motif symbolizes a gatekeeper who protects Malang community from foreign attacks (the Coronavirus). Accordingly, re-exploring local values during disasters (pandemic) is pivotal to evoke the spirit of resistance and endurance during crises. Additionally, the Dwarapala batik motif will be a reminiscent artifact which marks a certain era, through which the future generation will be able to remind of past events.

Throughout this research, there is not batik with Dwarapala motif has been found. Most of the batik motifs in Malang come from the form of temple architect, Malang monument and lotus relief. The creation of Dwarapala batik motif enriches the repertoire of the Malangan batik motifs, especially Dwarapala is associated with the present context (pandemic Covid-19). It becomes interesting how the archives context about the past (Dwarapala area) is dialogued with the present context (Covid-19). This is also the spirit of exploring local wisdom as a source life in the midst of a covid pandemic situation. Therefore, the creation of this batik motif is important to be implemented.

\section{Research Method}

The method used in this research was L.H. Chapman's visual art creation consisting of three stages by Chapman in Setiawan [1], i.e., the first stage was finding ideas. Ideas were the beginning of creation. The idea of the batik motif we created was based on Dwarapala discussed in the previous research. The Dwarapala motif needed further observation, amplifying its concept, in regard to either its philosophy or designs (the motif, colors, ornaments, and complementary motif), and redesigning by several aesthetic and artistic considerations in relation to its implementation on cloth.

The second stage was refining, developing, and validating the ideas. In this stage, we conducted brainstorming and material observation (either technical or non-technical). We made some alternative sketches, which comprised primary and complementary batik motif, by taking the composition or pattern of the motif on cloth or future usage to be a clothing product into account. The process, starting from making sketches into a final product, was manual and/or digital. To corroborate the concept and philosophy, we performed a literature study and looked for relevant references from books or articles which discussed the object researched. Also, we interviewed historical experts who apprehended the shape and history of Dwarapala. The primary motif was the character Dwarapala, reinforced by the character snake. The latter character was selected as it came in large number in Arca Dwarapala. Besides, the motif was also supported by the visualization of the character Coronavirus, as that virus was the havoc bringing about this pandemic. The third stage was to refine the ideas found. The shapes were stylized, so Dwarapala, as an iconic bold character, was beautiful and elegant to be printed on cloth. The iconic characters of Dwarapala were Dwarapala, cudgel, skull ornament, snake ornament, and the Coronavirus which strengthened the concept. After redesigning the Dwarapala batik motif, we could proceed to color and set the layouts digitally. 
In the third stage, we made an experiment, in which we created batik based on the character Dwarapala. Due to the Covid-19 pandemic, we preferred printing to draw the motif on cloth. The method was also selected as we had some constraints in movements, time, and energy. In printing, we selected the motif and began the layout printing and color matching processes.

\section{Result and Findings}

Dwarapala Statue has strong relation to the temple, because the existence is the entrance of the temple. But not all temples in Indonesia have Dwarapala in the area. In East Java especially Malang, Dwarapala has only in the temple area of Singosari in Renggo village, Singosari District. Dwarapala Statue in Singosari Temple can be found in the South and North, they are apart for at least 20 meters. They have size for about 3,7 meters, with body diameter of 3,8 meters. Dwarapala in Singosari Temple still to and both have the same shape, so it can be called "twin giants" [3].
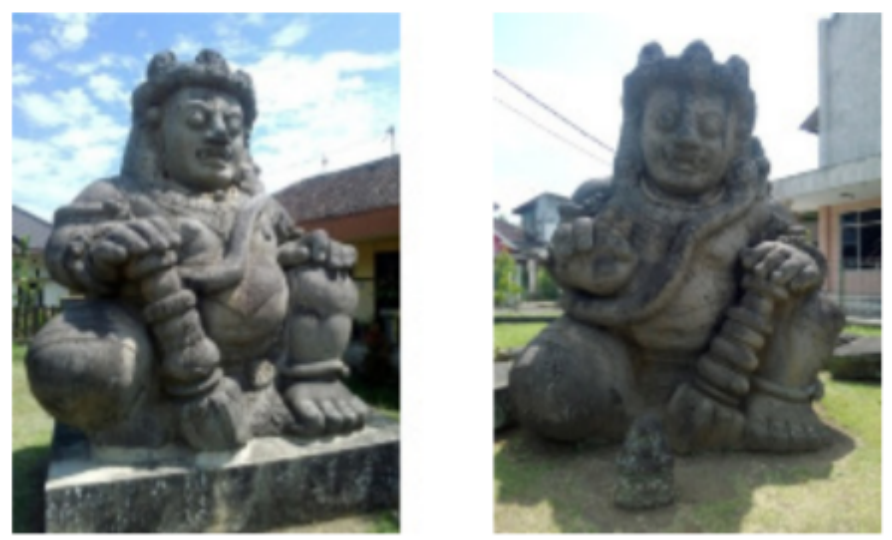

Fig. 1. Dwarapala Statue.

Findings indicate that Arca Dwarapala was a big and strong figure. He was a giant by shape and influential in character. His face was scary as he was the symbol of worldliness and protector from evil spirits. Furthermore, jewelry and attributes worn by Dwarapala signified the world of humanity and divinity. Furnished and luxurious jewelry (bracelets and ropes in a snake shape) depicted the world of human and worldliness. Meanwhile, his attributes, namely a cudgel and snake rope symbolized divinity. A strapping body and a hand with a weapon symbolized vigilance. Overall, considering its sitting position and posture, Arca Dwarapala was deemed as a gatekeeper and protector who drove evil spirits and dangers away. Additionally, we identified two primary motifs, which were 1) the primary motifs, i.e., the character Dwarapala, skull ornament, snake ornament, cudgel, the hand with a mudra position and 2) decorative motifs, i.e., a lotus flower (padma) and tendrils on Arca Dwarapala. The two primary motifs were then combined with the iconic character Coronavirus (complementary motif), generating a visual meaning as a gatekeeper who protected the community from the Coronavirus. 


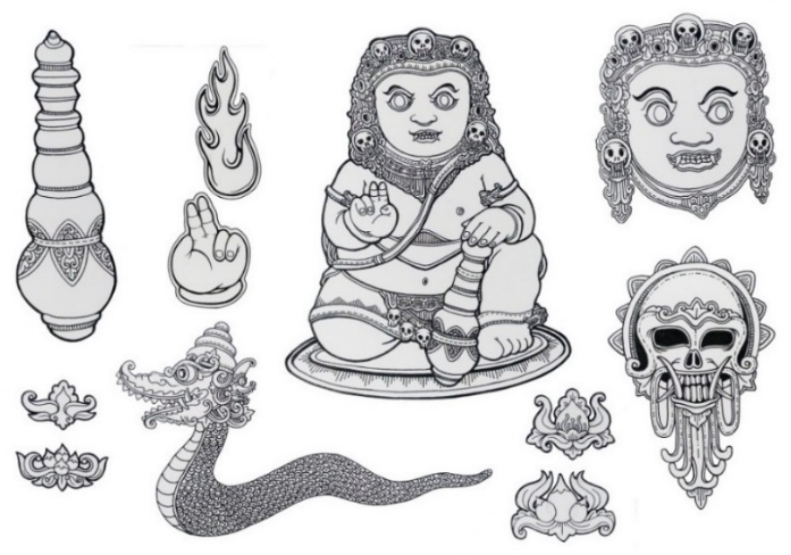

Fig. 2. Icons of the Character Dwarapala.

We concluded that the current Dwarapala batik motif should be re-designed. The latest design of Dwarapala-based batik motif was applied on cloth by adjusting its composition and the complementary motif and considering artistic and aesthetic aspects and making the main character Dwarapala preeminent. Shape exploration referred to the icons of the current Dwarapala character, namely the character Dwarapala, skull ornament, snake ornament, cudgel, and hand with a mudra position. Additionally, the imagery of Dwarapala as a protector from evil spirits and bad luck was the key aspect in redesigning our Dwarapala-based batik motif.

Indonesia was in a global emergency health situation. The Covid-19 had massively changed the world and impacted not only health sectors but also all sectors. The pandemic had entrapped the majority of the Indonesian community in an inconveniently unusual situation. When facing off the pandemic, we had to pray for safety. After the pandemic, we had to keep praying and try to reimburse any chance missing. Meanwhile, the pandemic had imbued us to redesign the Dwarapala batik motif.

Arca Dwarapala philosophically symbolized an area being protected. It protected the community from the current situation, which indicated a global emergency health situation due to the pandemic. The pandemic had a serious impact on not only the health sector but also other sectors. The community was expecting that the Covid-19 would immediately end. In this context, the motif or character Dwarapala constituted a gatekeeper and protector from the Covid-19 transmission.

We gave a detailed explanation of the Arca Dwarapala batik motifs, which were the primary and complementary motifs as well as the fillers.

\subsection{The Primary Motif Dwarapala}

The character Dwarapala was in a partial visualization but remained iconic. We retained the skull ornament on the headband (kapala) and necklace (kapala hara). The cudgel held by Arca Dwarapala in Singhasari Temple was facing down, depicting safety. However, in this particular motif, the cudgel (wajra) was held up, signifying a standby position to defend against 
the Coronavirus. Besides the character Dwarapala with his cudgel, the primary motif also contained fire ornaments symbolizing Dwarapala's spirit.

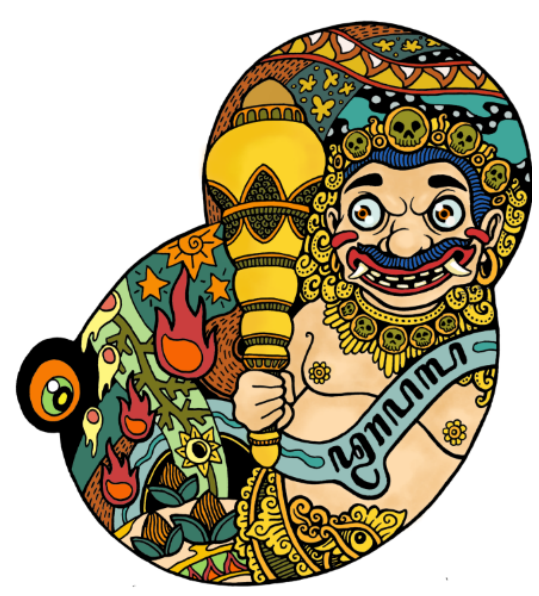

Fig. 3. The Primary Motif Dwarapala.

\subsection{The Primary Motif Snake}

The snake ornament on Arca Dwarapala was prominently iconic. This ornament decorated the shoulder straps (sapa keyura), bracelet (bhujangga valaya), rope looping around the shoulder (yajnopavita), and anklet (bhujangga nupura). The hand gesture, which was in a mudra position, depicted happiness. It was also visualized in this primary motif. The middle and index fingers were pointed up, whereas the other three were closed in the palm of the hand. The gesture was only found in Dwarapala placed in Singhasari Temple.

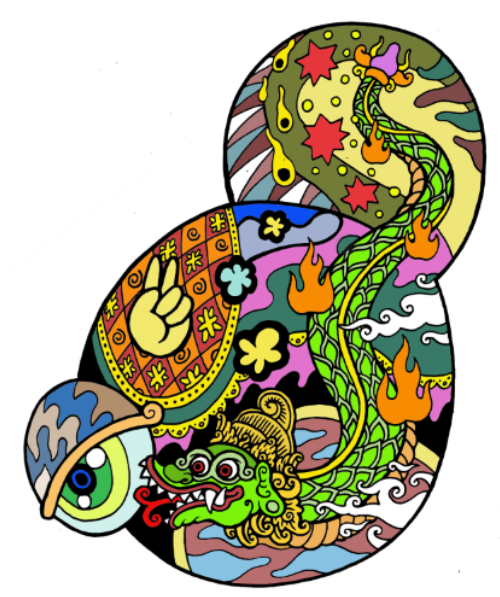

Fig. 4. The Primary Motif Snake.

Skull and snake ornaments on Arca Dwarapala were two distinctive characteristics of art styles in the Singhasari era, which referred to the teachings of Siva Buddha, particularly in 
relation to Tantra. The two motifs were peanut-like, illustrating the Indonesian proverb "Bagai Kacang Lupa Kulitnya", literally translated into "A peanut which forgot its nutshell", which, in accordance with an Indonesian dictionary, meant 1) A poor man who, after becoming wealthy in possessions, forgot his root, 2) A man who became arrogant and forgot his root. To put it short, he was arrogant and forgot his root. The ornaments reminded us not to abandon history. Instead, we should respect them by, e.g., preserving historical artifacts, such as arca (statues) or temples. A peanut, when you peel the skin, would be symmetrically split. This was regarded as a symbol of balance and fairness.

\subsection{The Complementary Motif Coronavirus}

Based on our visualization, the Coronavirus was round by shape with a diameter of 100120 nanometers $(\mathrm{nm})$. The virus was visually aesthetic. Observed using a microscope, it had nails which covered its surface like a crown. Manifested as a complementary motif, the Coronavirus was visualized with a round-shape character with one or two big eyes, two scary canine teeth, and a giant-like face.

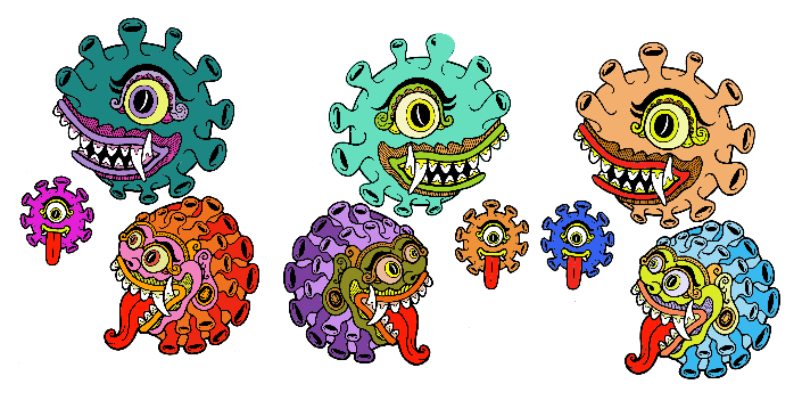

Fig. 5. The Complementary Motif Coronavirus.

The entire motifs, namely the primary motif Dwarapala, the primary motif snake, and the complementary motif Coronavirus were artistically and aesthetically adjusted to the size of cloth as media. A visual artwork was born after a creating process, which was called an artistic process. An artistic artwork had proper composition and meanings. Within a composition, we would identify the elements of visual art, i.e., lines, shapes, colors, and others and art principles, e.g., harmony, unity, and others. An artistic artwork was an aesthetic artwork. Beauty was not only in the eyes of beholders but also in its contexts. Artworks were not merely about technical aspects, rather, it had some other appeals of how artists reflected their ideas through their artworks. As such, the batik motif Dwarapala was one of the artists' contributions to evoke people's spirit and hopes to confront the pandemic, continue our lives, and respect the process. 

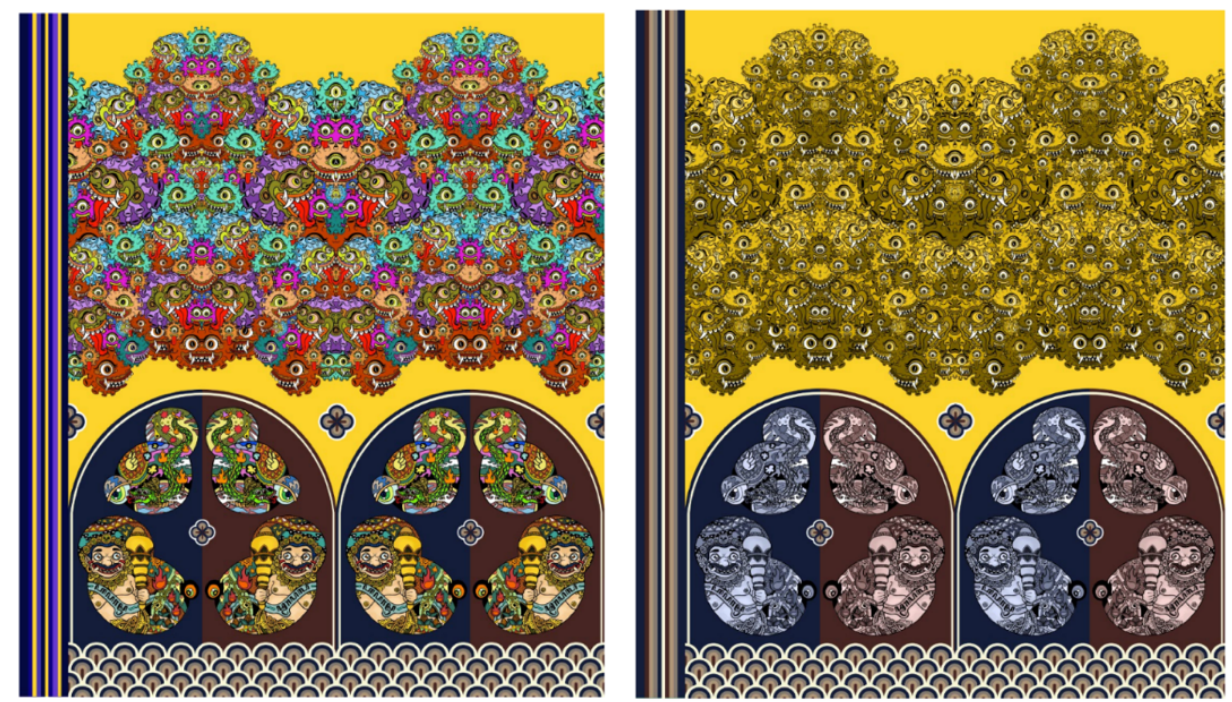

Fig. 6. The Dwarapala Batik Motif.

Two nuances of color, which were monochrome and full, were selected as the alternative for the primary motif. The selection was based on the color we usually saw on classical batik and the contemporary one. Meanwhile, in regard to the complementary motif Coronavirus, it was aimed to amplify the characteristics and concept of Dwarapala as a gatekeeper and protector. The motif had visual eyes, mouth, teeth which purposively resembled Dwarapala. The two primary motifs interacted with the iconic complementary character Coronavirus on cloth, creating a visual meaning as a gatekeeper and protector which were prepared in protecting the community from the Coronavirus.

\section{Conclusions}

Creating batik as a manifestation of artwork was expected to give a contribution to national cultural heritage preservation. Designing a Dwarapala character as one of the alternatives for printed batik generated a unique and distinguished batik, with respect to either its concept or visualization. We are expecting that the community will acknowledge not only the batik product but also Singhasari Temple, specifically Arca Dwarapala, as our inspiration. Finally, we are also expecting that this Dwarapala motif can be extensively applied as one of the alternative batik motifs from Malang.

\section{References}

[1] R. Setiawan, "Kinara Kinari Pada Relief Candi Badut Sebagai Ide Penciptaan Motif Batik Malangan," Imajin. J. Seni, vol. 13, no. 2, pp. 35-42, 2019.

[2] M. Stutley and J. Stutley, "Harper's Dictionary of Hinduism: Its Mythology, Folklore," Philos. 
Lit. Hist., 1977.

[3] D. Pradhikta, "Dwarapala in Singosari Temple's Relief as Idea for Creating Malangan Batik Motif,” Imajin. J. Seni, vol. 12, no. 2, pp. 77-84, 2018. 